\title{
Polyadenylylation in mycobacteria: evidence for oligo(dT)-primed cDNA synthesis
}

\author{
Tadepalli Adilakshmi, Peter D. Ayling and Colin Ratledge \\ Author for correspondence: Colin Ratledge. Tel: +44 1482 465243. Fax: +44 1482465458. \\ e-mail: c.ratledge@biosci.hull.ac.uk
}

Department of Biological Sciences, University of Hull, Hull HU6 7RX, UK

\begin{abstract}
The ability of mRNA to direct synthesis of CDNA in the presence of oligo(dT) was analysed using a novel application of fluorescein-11-dUTP incorporation into CDNA by reverse transcriptase. Evidence is provided for the first time that a majority of the mycobacterial mRNA pool is polyadenylylated. mRNA transcripts of hsp65 were also amplified with specific primers from the oligo(dT)-primed cDNA preparation in Mycobacterium bovis BCG, $M$. smegmatis and $M$. vaccae. Furthermore, PCR amplication of CDNAs for genes entD, entC and trpE2 from $M$. bovis BCG yielded the expected products when reverse transcription was primed with oligo(dT), suggesting that polyadenylylation is a general phenomenon in mycobacteria.
\end{abstract}

Keywords: mycobacteria, polyadenylylation, mRNA, oligo d(T), fluorescein-11-dUTP

\section{INTRODUCTION}

Post-transcriptional modification of the mRNA precursor is an essential step in mRNA maturation in eukaryotes, and defects in mRNA $3^{\prime}$-end formation can profoundly alter cell viability, growth and development (Zhao et al., 1999). In most cases, poly(A) elongation confers translational activation while de-adenylylation promotes translational silencing (Richter, 1999). There is growing evidence for the occurrence of polyadenylylated mRNAs in a variety of prokaryotes (Sarkar, 1997). Unlike poly(A) tracts in eukaryotic mRNA, which range between 80 and 200 nucleotides, poly $(\mathrm{A})$ tracts in prokaryotes range between 14 and 60 nucleotides and, moreover, polyadenylylation occurs at all unprotected RNA 3'-termini irrespective of their secondary structure. The functions of bacterial RNA polyadenylylation are quite diverse, ranging from the control of plasmid replication to the modulation of mRNA stability, as well as a possible role in mRNA translation (Sarkar, 1997). The discovery of the oligo(dT)-dependent synthesis of DNA complementary to bacterial mRNA (cDNA) by reverse transcriptase was an important advance in the study of bacterial poly(A) RNA, which paved the way for subsequent analysis at the molecular level. Reverse transcriptase requires a primer that hybridizes to the mRNA prior to cDNA synthesis. The oligo(dT) hybridizes to the 3'-poly(A) tail of the mRNA and allows the enzyme to initiate cDNA synthesis. We report here evidence for oligo(dT)-

Abbreviation: DEPC, diethylpyrocarbonate. dependent cDNA synthesis in three species of mycobacteria by using RT-PCR. We also describe the incorporation of fluorescein-11-dUTP into cDNA as a novel application for fluorescein. This reaction can be performed as a useful control to check the integrity of a bulk mRNA preparation in construction of a cDNA library, since the ability of mRNA to direct synthesis of long molecules of first-strand cDNA is a sign of mRNA integrity. Fluorescein-11-dUTP is commonly used for 3'end labelling of oligonucleotides (Cunningham et al., 1996) and for in situ hybridization (Wiegant et al., 1991).

The ent $C$ and entD genes that have been used in this work were selected because of their possible involvement in iron utilization (Cole et al., 1998). We presume that these genes are involved in the biosynthesis of salicylic acid, which occurs as a response of mycobacteria to deprivation of iron (Ratledge, 1999; Adilakshmi et al., 2000). Another gene, mbtI (trpE2) was also included in this study as Quadri et al. (1998) suggested that the protein product of this gene from Mycobacterium tuberculosis was homologous to salicylate- and anthranilate-forming enzymes from various other bacteria and therefore could be responsible for salicylate formation. In addition, hsp65, encoding a wellcharacterized $65 \mathrm{kDa}$ antigen in mycobacteria (Shinnick, 1987), was used.

\section{METHODS}

Mycobacterial strains and growth conditions. Mycobacterium bovis BCG (Glaxo strain, batch P691), $M$. smegmatis strain $\mathrm{mc}^{2} 155$ and M. vaccae $\mathrm{R} 877 \mathrm{R}$ were grown in 


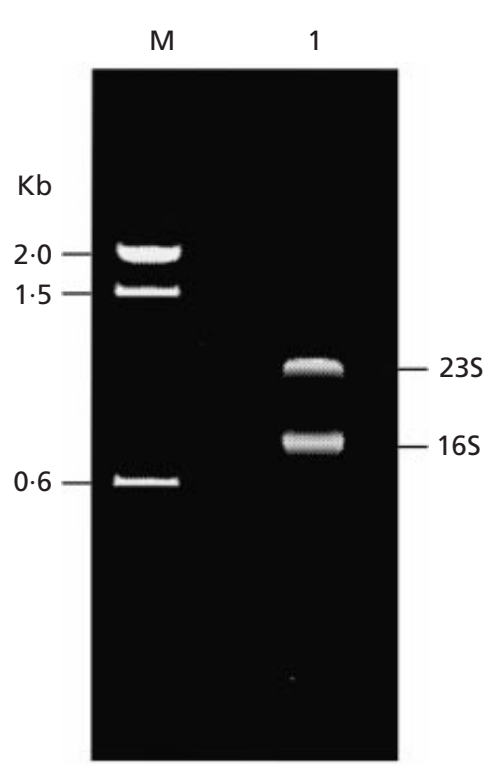

Fig. 1. Total RNA from $M$. bovis BCG separated by nondenaturing agarose gel electrophoresis $(1.5 \%, W / v)$ and stained with $0.5 \mu \mathrm{g}$ ethidium bromide $\mathrm{ml}^{-1}$. Lanes: $\mathrm{M}, 100 \mathrm{bp}$ DNA ladder; 1, RNA $(2 \mu \mathrm{g})$ purified from $M$. bovis BCG.

minimal medium containing $\left(\mathrm{g} \mathrm{l}^{-1}\right) \mathrm{KH}_{2} \mathrm{PO}_{4}$, 5; glycerol, 10; and asparagine, $5 ; \mathrm{pH} 7 \cdot 6$. Prior to inoculation, the medium was supplemented with $\left(\mu \mathrm{g} \mathrm{ml}^{-1}\right) \mathrm{Zn}^{2+}, 0 \cdot 45 ; \mathrm{Mn}^{2+}, 0 \cdot 1 ; \mathrm{Mg}^{2+}$ 40 ; and $\mathrm{Fe}^{2+}, 0 \cdot 05$, which gives iron-deficient growth and allows expression of genes involved in iron uptake and metabolism. Cultures were grown at $37^{\circ} \mathrm{C}$ on an orbital shaker at 200 r.p.m.

Genomic DNA isolation. Genomic DNA was isolated from mycobacteria according to the method of Gonzalez-yMerchand et al. (1996). Cells were collected from growth medium by centrifugation at $4000 \mathrm{~g}$ for $10 \mathrm{~min}$ and resuspended in $10 \mu \mathrm{l}$ lysis buffer per mg cells (wet wt). Lysis buffer was $6 \mathrm{M}$ guanidinium chloride, $1 \mathrm{mM}$ 2-mercaptoethanol, $10 \mathrm{mM}$ EDTA and $0 \cdot 1 \%$ Tween 80 . The cell suspension was subjected to two cycles of freeze-thawing by placing it in liquid $\mathrm{N}_{2}$ or ethanol $/ \mathrm{CO}_{2}$ freezing mixture for $1 \mathrm{~min}$ and then transferred to a water bath at $65^{\circ} \mathrm{C}$ for $10 \mathrm{~min}$. The resulting suspension was chilled on ice for $5 \mathrm{~min}$ and extracted twice with 2 vols chloroform/isoamyl alcohol, $(24: 1, \mathrm{v} / \mathrm{v})$. Two volumes of cold ethanol were added gradually and mixed gently by inverting the tube. This mixture was left at $-20^{\circ} \mathrm{C}$ for $30 \mathrm{~min}$. The DNA precipitate was recovered by centrifugation and dissolved in TE buffer $(10 \mathrm{mM}$ Tris $/ \mathrm{HCl}$, $1 \mathrm{mM}$ EDTA; pH 7.5) and stored at $-20{ }^{\circ} \mathrm{C}$ for further use.

RNA extraction. The method of Rajagopalan et al. (1995) was used to extract total RNA. One millilitre of the culture $\left(\mathrm{OD}_{600}\right.$ 0.5 ) was harvested, and centrifuged for $5 \mathrm{~min}$ at $4000 \mathrm{~g}$ at $4{ }^{\circ} \mathrm{C}$; the supernatant was discarded and $1.5 \mathrm{ml}$ Trizol reagent (phenol and guanidinium thiocyanate in a monophasic solution; Life Technologies) was added to the cell pellet. The suspension was ultrasonicated (Dawe Soniprobe) for $20 \mathrm{~s}$ followed by three cycles of freezing in liquid $\mathrm{N}_{2}$ and thawing at $4{ }^{\circ} \mathrm{C}$. The cell debris was removed by centrifugation for 2 min at $4000 \mathrm{~g}$. The supernatant was extracted with $0.75 \mathrm{ml}$ chloroform. RNA was precipitated by adding $0.6 \mathrm{ml}$ propan2-ol and incubating for $10 \mathrm{~min}$ at room temperature. The RNA pellet was recovered by centrifugation at $12000 \mathrm{~g}$ for
$15 \mathrm{~min}$ at $4{ }^{\circ} \mathrm{C}$. It was then washed once with $70 \%(\mathrm{v} / \mathrm{v})$ ethanol prepared in diethyl pyrocarbonate (DEPC)-treated water and resuspended in $40 \mu \mathrm{l}$ RNase-free, DEPC-treated water using the method of Sambrook et al. (1989). RNA was quantified in a GeneQuant II analyser (Pharmacia Biotech) by measuring $A_{260}$. The $A_{260} / A_{280}$ ratios for the RNA preparation were in the range $1 \cdot 8-2 \cdot 0$.

DNase treatment. RNA $(1 \mu \mathrm{g})$ was treated with 5 units DNase I (Life Technologies) and incubated at $25^{\circ} \mathrm{C}$ for $10 \mathrm{~min}$ to remove contaminating chromosomal DNA. EDTA $(1 \mu \mathrm{l}$ of $25 \mathrm{mM}$ ) was then added and the enzyme inactivated by heating to $65^{\circ} \mathrm{C}$ for $15 \mathrm{~min}$. The reaction mix was extracted with chloroform; the aqueous phase was precipitated with chilled propan-2-ol and centrifuged at $12000 \mathrm{~g}$ for $10 \mathrm{~min}$ at $4{ }^{\circ} \mathrm{C}$. The supernatant was discarded and the pellet was once again washed with $70 \%(\mathrm{v} / \mathrm{v})$ ethanol and recentrifuged at $12000 \mathrm{~g}$ for $10 \mathrm{~min}$ at $4{ }^{\circ} \mathrm{C}$. The pellet was then suspended in $20 \mu \mathrm{l}$ DEPC-treated water and requantified using the GeneQuant II analyser. The integrity of the RNA was checked on a $1.5 \%$ non-denaturing agarose gel as described by Mahenthiralingam (1998).

cDNA synthesis. Reverse transcription into cDNA was performed in $50 \mu \mathrm{l}$ containing $1 \mu \mathrm{g}$ RNA, $2 \mu \mathrm{g}$ oligo $\left(\mathrm{dT}_{12-18}\right), 20$ units RNAsin (both from Pharmacia), $10 \mathrm{mM}$ DTT, $10 \mu \mathrm{l}$ $5 \times$ nucleotide mix (dATP, dGTP, dCTP, dTTP and fluorescein-11-dUTP; Amersham), 10 units Superscript RNase $\mathrm{H}^{-}$reverse transcriptase (Life Technologies) and an appropriate volume of DEPC-treated water. The mixture was incubated for $1 \mathrm{~h}$ at $37^{\circ} \mathrm{C}$, chilled rapidly on ice and stored at $-20{ }^{\circ} \mathrm{C}$.

Southern blotting. cDNA samples were electrophoresed at $100 \mathrm{~V}$ through a $0.8 \%$ agarose minigel in $1 \times \mathrm{TBE}(45 \mathrm{mM}$ Tris/borate, $1 \mathrm{mM}$ EDTA). The cDNA could be seen directly under UV as a green fluorescent smear. However, resolution was better when it was stained with $0.5 \mu \mathrm{g}$ ethidium bromide $\mathrm{ml}^{-1}$ for $30 \mathrm{~min}$. The transfer of DNA from the gel to a nylon membrane was carried out overnight in $10 \times \mathrm{SSC}(3 \mathrm{M} \mathrm{NaCl}$, $0.3 \mathrm{M}$ sodium citrate, $\mathrm{pH} 7 \cdot 0$ ) by capillary blotting and the DNA was fixed by UV cross-linking (UV Stratalinker, Stratagene).

Detection of cDNA. The membrane was briefly rinsed with buffer A (100 mM Tris/ $\mathrm{HCl}, 600 \mathrm{mM} \mathrm{NaCl}$; pH 7.5) (2 ml $\mathrm{cm}^{-2}$ ) and incubated in anti-fluorescein-horseradish peroxidase antibody conjugate (ECL; Amersham), diluted 1000-fold in freshly prepared $0.5 \%(\mathrm{w} / \mathrm{v})$ bovine serum albumin fraction $\mathrm{V}$ in buffer $\mathrm{A}$ for $30 \mathrm{~min}$. Unbound conjugate was removed by washing the membrane for $3 \times 10$ min periods in excess buffer A containing $0 \cdot 1 \%$ (v/v) Tween 20 . The washed membrane was treated with detection solution mixture according to the manufacturer's instructions and exposed for $1 \mathrm{~h}$ to Hyperfilm (Amersham), which was then developed.

PCR. The technique of message-amplification phenotyping (mRNA phenotyping), an application of the PCR technique, was used to detect the mRNA transcripts of $h s p 65$, one of the well-characterized genes of mycobacterial metabolism (Shinnick, 1987), and entD, entC and trpE2 (see Introduction). Primers were designed using the Oligo 5.0 software and obtained from MWG-Biotech. All the other reagents used in the PCR reaction were from Life Technologies. The PCR mixture contained $2.5 \mu \mathrm{l}$ nascent cDNA, $2.5 \mu \mathrm{l} 10 \times$ PCR buffer, $1.5 \mathrm{mM} \mathrm{MgCl}_{2}, 200 \mu \mathrm{M}$ each of the dNTPs, $0.5 \mu \mathrm{g}$ each of oligonucleotide primers and 2 units Taq DNA polymerase, and was made up to a final volume of $25 \mu \mathrm{l}$ with sterile distilled water. Amplification was performed on a Peltier thermocycler (MJ Research) using the following thermocycle: $\left(94^{\circ} \mathrm{C}\right.$, $\left.1 \mathrm{~min} ; 55^{\circ} \mathrm{C}, 1 \mathrm{~min} ; \quad 72^{\circ} \mathrm{C}, 2 \mathrm{~min}\right) \times 30$ cycles; $\left(72{ }^{\circ} \mathrm{C}\right.$, 
$10 \mathrm{~min}) \times 1$ cycle. DNA bands were visualized on agarose gel electrophoresis and photographed using the UVIPhoto V.97 software on Windows 95. The identity of the PCR products was confirmed by restriction enzyme analysis. All restriction enzymes were from Life Technologies.

\section{RESULTS}

Total RNA was prepared from $M$. bovis BCG, $M$. smegmatis $\left(\mathrm{mc}^{2} 155\right)$ and $M$. vaccae as descibed in Methods. Low-iron $\left(0.05 \mu \mathrm{g} \mathrm{ml}^{-1}\right)$ growth medium was used to ensure the full expression of entD, entC and trpE2. To assess the quality of the RNA, a small aliquot $(2 \mu \mathrm{g})$ of the preparation was electrophoresed on a $1.5 \%$ non-denaturing agarose gel. The appearance of the sharp bands corresponding to the $23 \mathrm{~S}$ and $16 \mathrm{~S}$ rRNA indicates the integrity of the RNA (Sambrook et al., 1989) (Fig. 1). To confirm the integrity of the bulk mRNA preparation without the use of radioisotopes, we used fluorescein-11-dUTP as a nucleotide precursor for cDNA synthesis catalysed by reverse transcriptase, since the ability of mRNA to direct the synthesis of long molecules of first-strand cDNA is a sign of its integrity. To study whether polyadenylylation is a universal phenomenon in mycobacteria, cDNA was prepared in the presence and absence of oligo(dT). A cDNA preparation with random nonamer primers was used as a positive control and a cDNA reaction mix without mRNA was used as a negative control. The cDNA was then analysed on $0.8 \%$ agarose gel and visualized under UV light after staining with ethidium bromide. A continuous smear of cDNA can be observed starting from $500 \mathrm{bp}$ to $>4 \mathrm{~kb}$ (Fig. 2a, lanes 4 and 5) and no bands were observed in the negative controls (Fig. 2a, lanes 2 and 3 ).

The gel was blotted on to a nylon membrane, which was treated with anti-fluorescein specific antibody and then exposed to Hyperfilm. The smear was seen at positions corresponding to positive controls (Fig. 2b, lanes 4 and 5) whereas no bands could be detected at the negative control positions (Fig. 2b, lanes 2 and 3). It is evident that the cDNA preparation made in the presence of oligo(dT) (lane 4) reflects the complete integrity of mRNA equivalent to that observed with random priming. Synthesis of cDNA appears to be primed by oligo(dT), suggesting the occurrence of a polyadenylylated mRNA population in mycobacteria.

(a)
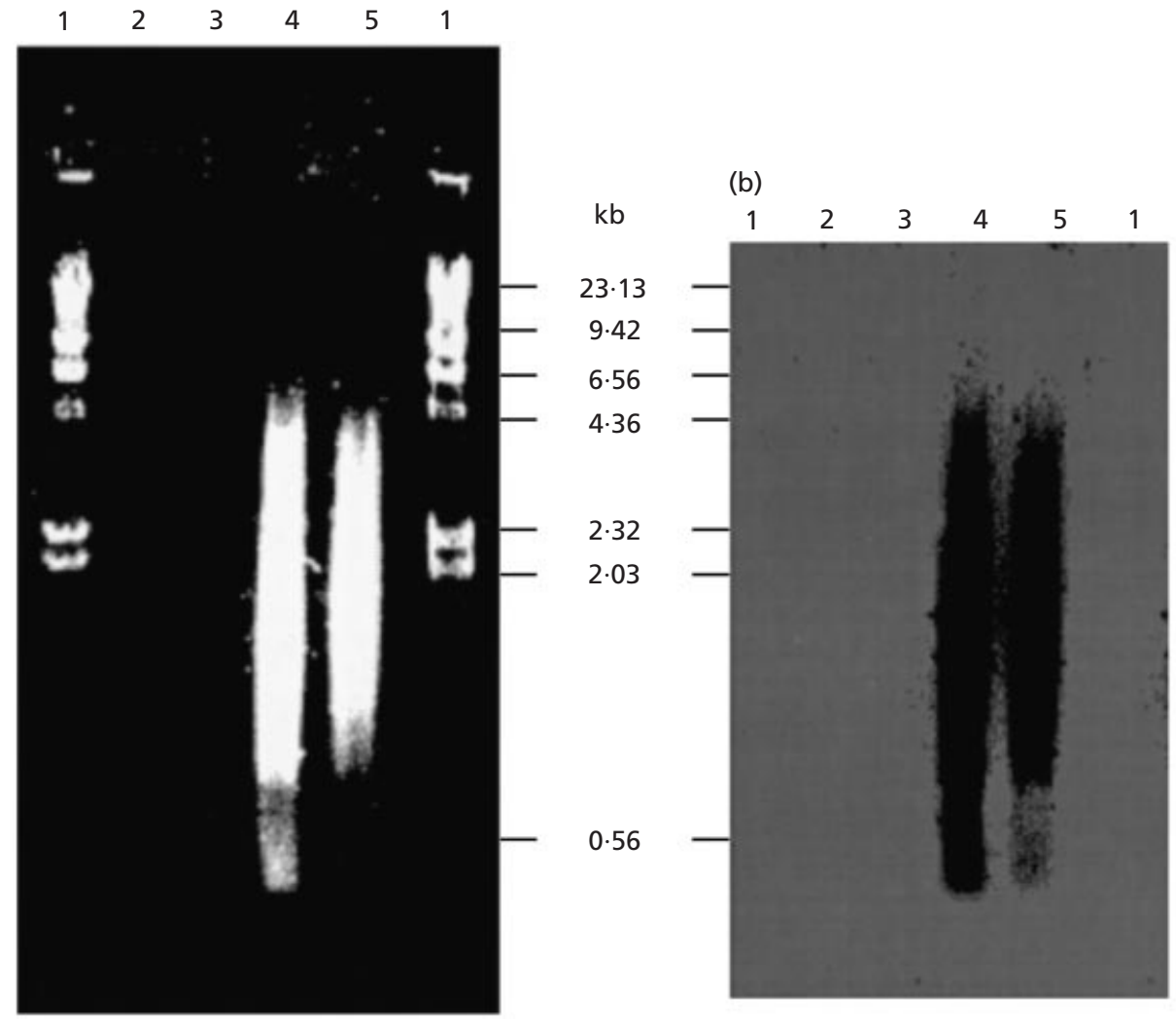

Fig. 2. Synthesis of CDNA in presence and absence of oligo(dT) or random nonamer primer. (a) The cDNA prepared from RNA in the presence of oligo(dT) was separated on a $0.8 \%$ agarose gel and stained with $0.5 \mu \mathrm{g}$ ethidium bromide $\mathrm{ml}^{-1}$. Lanes: 1, $\lambda$-HindIII marker; 2, cDNA reaction mix without mRNA (negative control); 3, cDNA reaction mix without oligo(dT) (negative control); 4, cDNA preparation with random nonamer primers (positive control); 5 , cDNA in presence of oligo(dT). (b) Immunoblotting of cDNA with anti-fluorescein-horseradish peroxidase conjugate antibody. Lanes as in (a). 
Table 1. PCR primers, position of primers, product sizes and restriction enzyme analysis of the genes used in this study

\begin{tabular}{|c|c|c|c|c|}
\hline Gene & Primers $\left(5^{\prime}-3^{\prime}\right)$ & $\begin{array}{l}\text { Nucleotide } \\
\text { positions in } \\
\text { the gene }\end{array}$ & $\begin{array}{l}\text { Expected } \\
\text { product } \\
\text { size }(b p)\end{array}$ & $\begin{array}{l}\text { Restriction } \\
\text { enzyme and } \\
\text { product size } \\
\text { (bp) }\end{array}$ \\
\hline \multirow[t]{2}{*}{ hsp65 } & ACC AAC GAT GGT GTG TCC AT (Forward) & $396-415$ & 441 & $\operatorname{HinfI}(385+56)$ \\
\hline & CTT GTC GAA CCG CAT ACC CT (Reverse) & $817-836$ & & \\
\hline \multirow[t]{2}{*}{ entD } & GGC GTG CGT AAC CAC CGA TTG CTA CT (Forward) & $4-29$ & 534 & $\operatorname{HinfI}(298+236)$ \\
\hline & GCA GAT CCT GAT CGA GGC GGT GGG CA (Reverse) & $512-537$ & & \\
\hline \multirow[t]{2}{*}{ entC } & TTG CAC CCA GAA CCA CCG TTC GCA CT (Forward) & $22-47$ & 963 & $\operatorname{Not} \mathrm{I}(599+364)$ \\
\hline & TTG CTC GCA CCT GAT AGA CAG CAC CC (Reverse) & $959-984$ & & \\
\hline \multirow[t]{2}{*}{$\operatorname{trp} E 2$} & TAA GGC GTC AAT GTG GAT AGC TTT T (Forward) & $236-261$ & 1148 & BamHI $(301+847)$ \\
\hline & ATG GTG GAG CTA GAC AGC GAC GAA C (Reverse) & $1359-1384$ & & \\
\hline
\end{tabular}

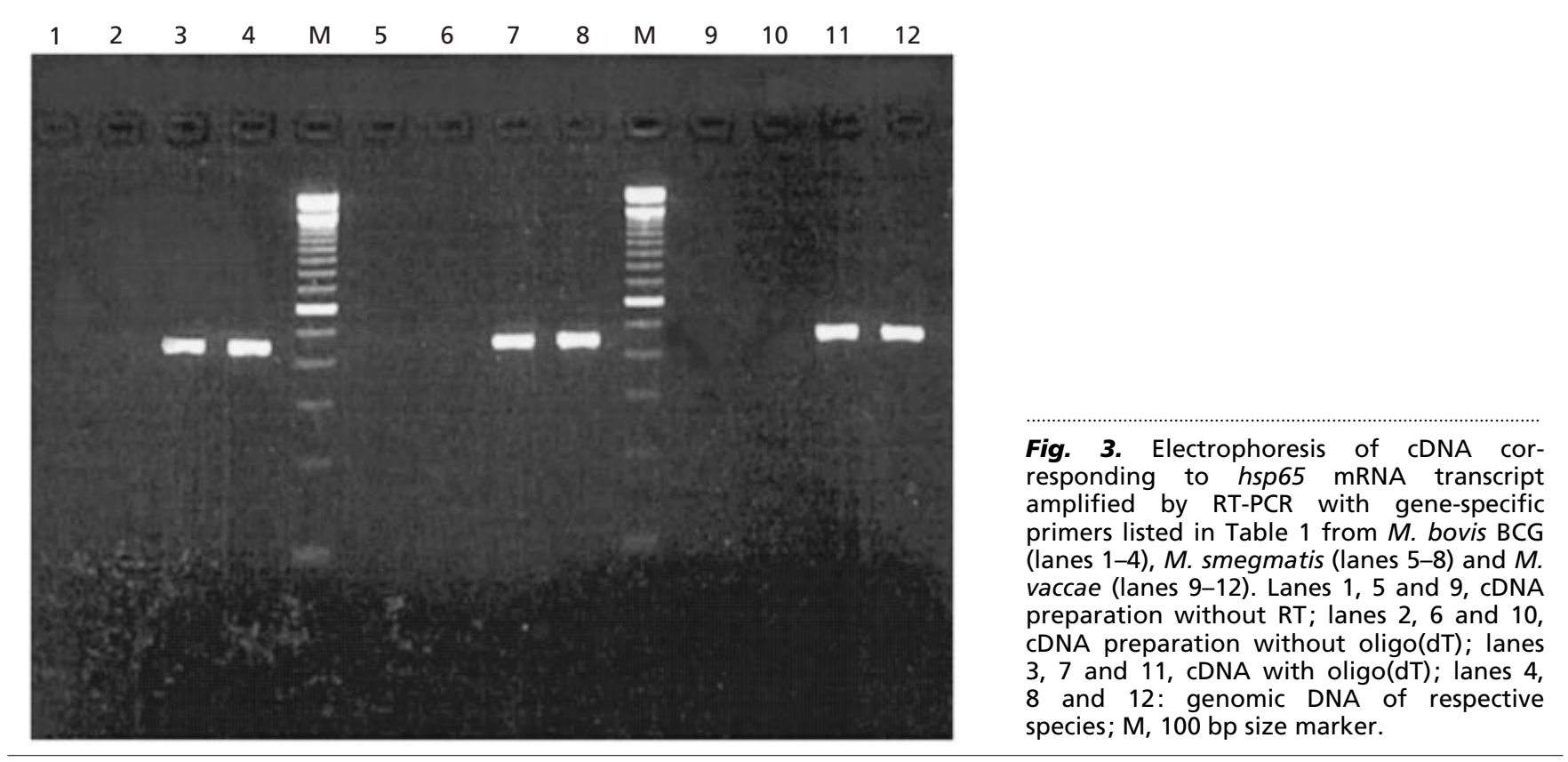

Specific mRNA transcripts of $h s p 65$ were amplified with gene specific primers (Table 1) in three species of mycobacteria, M. bovis BCG, M. smegmatis and $M$. vaccae (Fig. 3). As expected, a 441 bp sequence corresponding to the $h s p 65$ product was observed. It is clear that the amplification of $h s p 65$ was markedly pronounced in the cDNA prepared in presence of oligo(dT) alone (lanes 3, 7 and 11) and was equivalent to that obtained with genomic DNA amplification (lanes 4, 8 and 12).

Further, mRNA transcripts of entD, entC and trpE2 were amplified from $M$. bovis BCG by RT-PCR using the gene specific primers shown in Table 1 and, again, transcripts could be detected in cDNA preparations made in presence of oligo(dT) (Fig. 4, lanes 3, 5 and 7) but not in the absence of oligo(dT) (lane 2). Negative controls were obtained for entC and trpE2 transcripts as well (data not shown). Again, the size of the RT-PCR product was equal to that amplified from the genomic
DNA preparation (Fig. 4, lanes 4, 6 and 8). The RT-PCR products for $h s p 65$, entD, entC and trpE2 were confirmed by restriction enzyme analysis as shown in Fig. 5. The products match those listed in Table 1, establishing the identity of the PCR products.

\section{DISCUSSION}

In the construction of a cDNA library, the first step consists in the extraction of mRNA and its reverse transcription into cDNA. During these procedures, it is important to control the integrity of the mRNA preparation before it is used as a template for the synthesis of the first strand of cDNA. We describe here a nonradioactive method to check the integrity of $\mathrm{mRNA}$ by analysing its ability to direct the synthesis of first-strand cDNA in the presence of fluorescein-11-dUTP. The method of labelling cDNA with fluorescein-11-dUTP is as effective as the radioactive method and it may be 


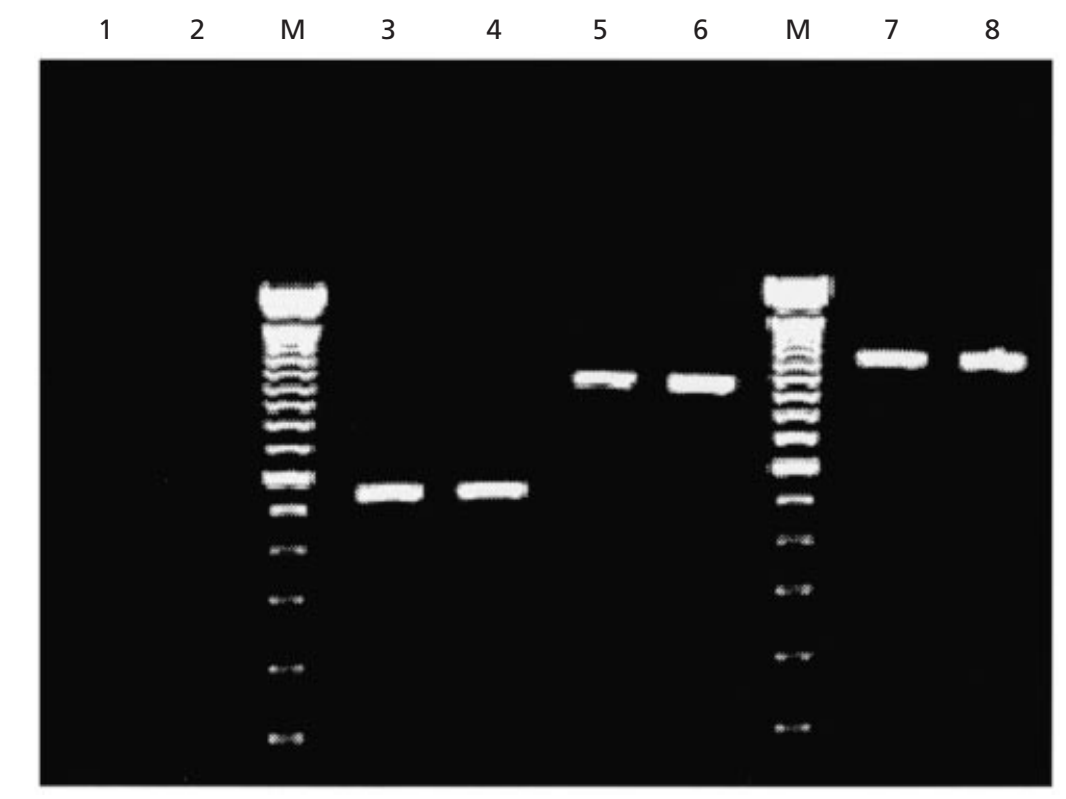

Fig. 4. Electrophoresis of of entD, entC and trpE2 mRNA transcripts amplified by RT-PCR from $M$. bovis BCG amplified with genespecific primers listed in Table 1. Lanes: 1, CDNA reaction mix without $\mathrm{RT}$ and amplified with primers for entD (negative control); lane 2, CDNA reaction mix without oligo(dT) and amplified with primers for entD (negative control); lanes $3 \& 4$, PCR of entD carried out with CDNA preparation made in the presence of oligo(dT) and genomic DNA respectively; lanes $5 \& 6$, PCR of entC carried out with CDNA preparation made in the presence of oligo(dT) and genomic DNA respectively; lanes $7 \& 8$, PCR of trpE2 carried out with CDNA preparation made in the presence of oligo(dT) and genomic DNA respectively; $M, 100 \mathrm{bp}$ size marker.

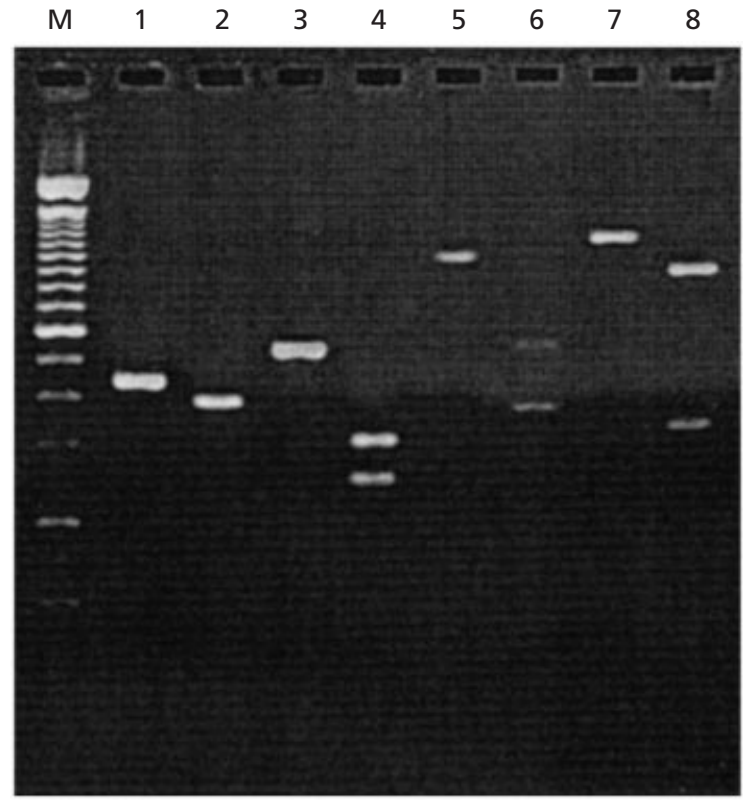

Fig. 5. Restriction enzyme analysis of RT-PCR products of $h s p 65$, entD, entC and trpE2 of $M$. bovis BCG. Lanes: 1, hsp65; 2, Hinfl digest of hsp65; 3, entD; 4, Hinfl digest of entD; 5, entC; 6 , Notl digest of entC; 7, trpE2; 8, BamHI digest of trpE2.

preferred because the hazards related to the use of radioactive compounds are eliminated. Owing to the high $\mathrm{G}+\mathrm{C}$ content of mycobacterial DNA, one might expect self-priming to occur due to the folding back of mRNA. However, we could not detect any cDNA synthesized in the absence of either primer [random/ oligo(dT)], thus ruling out a self-priming mechanism. As expected in the presence of random primers, many smaller fragments were evident in the cDNA preparation resulting from incomplete synthesis (Fig. 2b).
Little is known about gene expression patterns of mycobacteria; the definition of differentially expressed genes is central to understanding pathogenesis and virulence at a molecular level. The application of techniques such as differential display and subtractive hybridization, commonly used for the analysis of eukaryotic gene expression, has been limited in prokaryotes, owing to the generally accepted view that $3^{\prime}$ polyadenylylation of mRNA is a eukaryotic feature. Differential display in prokaryotes therefore requires the use of non-specific, random arbitrary primers (RAP) for cDNA synthesis, often involving extensive testing and optimization of primers (Kwaik \& Pederson, 1996; Fislage et al., 1997; Rivera-Marrero et al., 1998). In addition, reamplification by PCR and subcloning of the isolated cDNA fragments is often difficult and results in failure. The main problem found with the RAP-PCR method is that, due to the abundance of rRNA and variations in the amount of rRNA in RNA preparations from different strains, amplification with arbitrary primers often results in a high number of false positives. Our finding therefore represents a significant advance in the study of gene expression in mycobacteria, as oligo $(\mathrm{dT})$-primed cDNA synthesis eliminates the pitfalls encountered with techniques such as RAP-PCR.

Sequential addition of adenylate residues to 3 '-termini of RNA molecules is catalysed by the enzyme poly (A) polymerase (ATP:polyribonucleotide adenylyltransferase, EC 2.7.7.19). Multiple isoforms of poly(A) polymerases, probably derived from a single gene by alternate splicing or post-translational modification, occur in eukaryotes (Thuresson et al., 1994). In contrast, there is growing evidence for the occurrence of more than one such enzyme encoded by different genes ( $p c n A$ and $p c n B)$ in Escherichia coli (Sarkar, 1997). The deduced product of $p c n B$ (PAP I), however, showed no homology to eukaryotic poly(A) polymerases and even moderate overexpression of this gene was lethal to $E$. 
coli (Cao \& Sarkar, 1992). On the other hand, disruption of this gene decreased the growth rate by two-thirds (Liu $\&$ Parkinson, 1989). The protein product of $p c n A$ of $E$. coli (PAP II) has no significant sequence homology either to PAP I or to the viral and eukaryotic poly(A) polymerases (Kalapos et al., 1994), suggesting that the bacterial poly(A) polymerases have evolved independently. Sarkar (1997) suggested that PAP I and PAP II possibly polyadenylate complementary classes of mRNA, or one enzyme initiates poly $(\mathrm{A})$ chains and the other functions in their extension, and that the deletion of both the genes would be lethal to the organism. In Saccharomyces cerevisiae, there is a single gene for poly (A) polymerase whose inactivation leads to the loss of viability (Lingner et al., 1991). The protein product of the pcnA gene $(\mathrm{Rv} 3907 \mathrm{c}$; Cole et al., 1998) of $M$. tuberculosis has $80 \%$ similarity (BLASTP search) to the poly $(\mathrm{A})$ polymerase-encoding gene $p c n B$ of $M$. leprae (accession no. AAB53125; Fsihi et al., 1996), suggesting that this gene is conserved in mycobacteria. In addition, this protein has a high similarity to poly $(\mathrm{A})$ polymerases from various organisms including Bacillus subtilis, E. coli and Helicobacter pylori, supporting our finding that polyadenylylation does occur in mycobacteria. Understanding the importance of $p c n A$ and $p c n B$ to the survival of M. tuberculosis and M. leprae, respectively, might therefore open a new area for drug design to combat these pathogens.

\section{ACKNOWLEDGEMENTS}

M. smegmatis $\mathrm{mc}^{2} 155$ and $M$. vaccae were kind gifts from Professor Issar Smith, USA, and Professor John Stanford, UK, respectively. The authors also thank Professor Jeremy Dale, University of Surrey, UK, for helpful comments on the manuscript and Dr David Lunt, University of Hull, UK, for his help with designing the primers. T.A. gratefully acknowledges receipt of a Sir Brynmor Jones research studentship from the University of Hull.

\section{REFERENCES}

Adilakshmi, T., Ayling, P. D. \& Ratledge, C. (2000). Mutational analysis of a role for salicylic acid in iron metabolism of Mycobacterium smegmatis. J Bacteriol 182, 264-271.

Cao, G.-J. \& Sarkar, N. (1992). Identification of the gene for an Escherichia coli poly(A) polymerase. Proc Natl Acad Sci USA 89, 10380-10384.

Cole, S. T., Brosch, R., Parkhill, J. \& 39 other authors (1998). Deciphering the biology of Mycobacterium tuberculosis from the complete genome sequence. Nature 393, 537-544.

Cunningham, M., Durrant, I. \& Harvey, B. (1996). 3'-end labeling of oligonucleotides with fluorescein-11-dUTP and enhanced chemiluminescent detection. Methods Mol Biol 58, 77-82.

Fislage, R., Berceanu, M., Humboldt, Y., Wendt, M. \& Oberender, H. (1997). Primer design for a prokaryotic differential display RTPCR. Nucleic Acids Res 25, 1830-1835.

Fsihi, H., De Rossi, E., Salazar, L., Cantoni, R., Labò, M., Riccardi, G., Takiff, H. E., Eiglmeier, K., Bergh, S. \& Cole, S. T. (1996). Gene arrangement and organization in $\mathrm{a} \sim 76 \mathrm{~kb}$ fragment encom- passing the oriC region of the chromosome of Mycobacterium leprae. Microbiology 142, 3147-3161.

Gonzalez-y-Merchand, J. A., Estrada-Garcia, I., Colston, M. J. \& Cox, R. A. (1996). A novel method for the isolation of mycobacterial DNA. FEMS Microbiol Lett 135, 71-77.

Kalapos, M. P., Cao, G.-J., Kushner, S. R. \& Sarkar, N. (1994). Identification of a second poly(A) polymerase in Escherichia coli. Biochem Biophys Res Commun 198, 459-465.

Kwaik, Y. A. \& Pederson, L. L. (1996). The use of differential display-PCR to isolate and characterize a Legionella pneumophila locus induced during the intracellular infection of macrophages. Mol Microbiol 21, 543-556.

Lingner, J., Kellermann, J. \& Keller, W. (1991). Cloning and expression of the essential gene for poly(A) polymerase from Saccharomyces cerevisiae. Nature 354, 496-498.

Liu, J. \& Parkinson, J. S. (1989). Genetics and sequence analysis of the $p c n B$ locus, an Escherichia coli gene involved in plasmid copy number control. J Bacteriol 171, 1254-1261.

Mahenthiralingam, E. (1998). Extraction of RNA from mycobacteria. Methods Mol Biol 101, 65-75.

Quadri, L. E., Sello, J., Keating, T. A., Weinreb, P. H. \& Walsh, C. T. (1998). Identification of a Mycobacterium tuberculosis gene cluster encoding the biosynthetic enzymes for assembly of the virulence-conferring siderophore mycobactin. Chem Biol 5, 631-645.

Rajagopalan, M., Boggaram, V. \& Madiraju, M. V. V. S. (1995). A rapid protocol for isolation of RNA from mycobacteria. Lett Appl Microbiol 21, 14-17.

Ratledge, C. (1999). Iron metabolism. In Mycobacteria: Molecular Biology and Virulence, pp. 260-286. Edited by C. Ratledge \& J. Dale. Oxford: Blackwell.

Richter, J. D. (1999). Cytoplasmic polyadenylylation in development and beyond. Microbiol Mol Biol Rev 63, 446-456.

Rivera-Marrero, C. A., Burroughs, M. A., Masse, R. A., Vannberg, F. O., Leimbach, D. L., Roman, J. \& Murtagh, J. J., Jr (1998). Identification of genes differentially expressed in Mycobacterium tuberculosis by differential display PCR. Microb Pathog 25, 307-316.

Sambrook, J., Fritsch, E. F. \& Maniatis, J. (1989). Molecular Cloning: a Laboratory Manual, 2nd edn. Cold Spring Harbor, NY: Cold Spring Harbor Laboratory.

Sarkar, N. (1997). Polyadenylation of mRNA in prokaryotes. Annu Rev Biochem 66, 173-197.

Shinnick, T. M. (1987). The 65-kilodalton antigen of Mycobacterium tuberculosis. J Bacteriol 169, 1080-1088.

Thuresson, A-C., Åström, J., Åström, A., Grönvik, K.-O. \& Virtanen, A. (1994). Multiple forms of poly(A) polymerases in human cells. Proc Natl Acad Sci USA 91, 979-983.

Wiegant, J., Ried, T., Nederlof, P. M., van der Ploeg, M., Tanke, H. J. \& Raap, A. K. (1991). In situ hybridization with fluoresceinated DNA. Nucleic Acids Res 19, 3237-3241.

Zhao, J., Hyman, L. \& Moore, C. (1999). Formation of mRNA 3' ends in eukaryotes: mechanism, regulation, and interrelationships with other steps in mRNA synthesis. Microbiol Mol Biol Rev 63, $405-445$.

Received 28 June 1999; revised 2 November 1999; accepted 20 December 1999. 